\title{
Circulation and Contacts in Sixteenth Century New Cartography: Spain, Portugal and Italy
}

\author{
José María Moreno Madrid \\ CIUHCT. University of Lisbon \\ e-mail: jmmadrid@fc.ul.pt \\ ORCID iD: https://orcid.org/0000-0002-9499-3474
}

Submitted: 3 February 2020. Accepted: 17 October 2020.

\begin{abstract}
Cartographic information was highly coveted in sixteenth century Europe, especially when it came from Portugal or Spain. Maps and nautical charts produced in the Iberian Peninsula were loaded with sensitive information about the new lands discovered, which made them the object of desire of rival or curious powers. Faced with this, the Spanish and Portuguese institutions tried to limit the excessive dispersion of cartographic material, using several legislative instruments. In theory, the circulation of cartographic information beyond Iberian imperial boundaries was strictly controlled, so the possibility of leakages or exchanges seemed very unlikely. In practice, both leaks and contact occurred constantly. The objective of this article is to illustrate this idea from the identification and analysis of concrete historical events in which the circulation of cartographic information took place. The chronological framework chosen is the sixteenth century, with Spain, Portugal and Italy as the main sites.
\end{abstract}

KEYWORDS: Early Modern cartography; Circulation of knowledge; Espionage; Iberian science.

Citation / Cómo citar este artículo: Moreno Madrid, José María (2021) “Circulation and Contacts in Sixteenth Century New Cartography: Spain, Portugal and Italy.” Culture \& History Digital Journal, 10 (2): e015. https://doi.org/10.3989/ chdj.2021.015

RESUMEN: Circulación y contactos en la nueva cartografía del siglo XVI: España, Portugal e Italia.- La información cartográfica fue un elemento altamente cotizado en la Europa del siglo XVI, sobre todo aquella que provenía de Portugal o España. Los mapas y cartas náuticas facturadas en la península ibérica estaban cargadas de informaciones sensibles sobre las nuevas tierras descubiertas, lo que las convertía en objeto de deseo de potencias rivales o sencillamente curiosas. Advertidas de esto, las instituciones españolas y portuguesas intentaron limitar la excesiva dispersión del material cartográfico, valiéndose de diversos instrumentos legislativos. En la teoría, la circulación de informaciones cartográficas más allá de los límites imperiales ibéricos estaba estrictamente fiscalizada, dejando un margen muy estrecho a la posibilidad de fugas o intercambios. En la práctica, tanto las sustracciones como los contactos ocurrían constantemente. El objetivo de este artículo es ilustrar esta idea a partir de la identificación y el análisis de eventos históricos concretos en los que la circulación de informaciones cartográficas se produjo, tomando como marco cronológico el siglo XVI y como potencias protagonistas a España, Portugal e Italia.

PALABRAS CLAVE: Cartografía de la Edad Moderna; Circulación de conocimiento; Espionaje; Ciencia ibérica.

Copyright: $\odot 2021$ CSIC. This is an open-access article distributed under the terms of the Creative Commons Attribution 4.0 International (CC BY 4.0) License. 


\section{INTRODUCTION}

The maritime expansion of Portugal and Spain during the sixteenth century led both Iberian empires to face situations of a political, social and economic nature that had never been handled before. Among the many problems generated by this new and complex reality was the need to control enormous masses of information coming into the Peninsula from the colonized territories. Both Portugal and Spain quickly realised that it was necessary to develop mechanisms to manage such a volume of information, which led to the appearance of specific institutions, most famously Armazens de Guiné e India (Lisbon) and Casa de la Contratación (Seville); intermediate professionals, including pilots, cosmographers and professors of cosmography; and new cognitive devices, such as pattern charts, regimentos and oceanic rutters (Leitão and Sánchez, 2017, pp. 202-204). Cartographic information, the focus of this study, was regulated using these mechanisms. Nautical charts, ${ }^{1}$ which became the reservoir of cartographic information par excellence during the Modern Age, incorporated data collected by intermediate professionals, were produced and updated in specific institutions ${ }^{2}$ and they themselves constituted a cognitive device of the highest level.

Thus, cartographic information underwent an evolutionary process from its most embryonic epistemic stages to being embodied in an easily understandable appearance on a physical support that could be transported on board a ship. ${ }^{3}$ Throughout this process and during the time that the nautical chart existed, there is a paradoxical need to simultaneously "hide and disseminate the geographical knowledge" (Sandman, 2008, p. 32) contained in it.

This paradox inevitably resulted in a theory-practice dichotomy. The theory was built on various legislative instruments established by the Iberian monarchs. In the case of Portugal, the first instruction aimed at restricting the circulation of cartographic information came in 1504, when King Manuel I "prohibited the construction of globes and the reproduction of maps of Africa beyond the Manicongo River" (Marcondes de Souza, 1958, p. 265; Paladini, 2000, p. 62). This order would fall within the framework of the Portuguese politica do sigilo, which had supposedly been implemented in the Portuguese kingdom to safeguard its overseas discoveries from the curious gaze of other powers of the time. ${ }^{4}$

Although certain considerations of the politica do sigilo are difficult to accept today, it is undeniable that measures were adopted to protect Portuguese nautical knowledge from excessive dispersion. Similar measures were also adopted in Spain for the same purpose. In 1510 the Casa de la Contratación prohibited the circulation of nautical charts or information about the Indies without its permission, imposed a prohibition on pilots to give, sell or lend nautical charts to foreigners, and chart makers were also prohibited from selling their charts to foreigners (Sandman, 2008, p. 34). ${ }^{5}$

These are some examples of the regulatory measures that were adopted in the early sixteenth century, and which were complemented by many others in subsequent years. I will return to them later, since for the time being those mentioned are sufficient to understand the framework on which the theory is built. This legislative apparatus, together with the cartographic studies of the nineteenth and a good part of the twentieth century, ${ }^{6}$ can lead us to think about the cartographic production of the sixteenth century as a set of national compartments that did not interact too much. Nevertheless, if one descends into practice, it will be noticed that it differed considerably from the main lines that the theory marked, and that nautical charts and cartographic information in general circulated beyond the limits dictated by the imperial authorities. Understanding the cartographic information of the Modern Age as a corpus of global knowledge in constant circulation already made sense for the imperial framework (Sánchez, 2019, pp. 35-36). But it could also make sense in a more "transnational" framework, considering the many contacts in the cartographic field that took place between different political-territorial entities during the sixteenth century. Of course, it would be a mistake to completely eliminate the relevance of the geographical factor. ${ }^{7}$ It is clear that maps and nautical charts will have unique characteristics associated with their production site. But was one hundred percent of the information contained in those documents of "national" origin? This is something hard to believe. On the contrary, it is more logical to think that it was the circulation of ideas and, therefore, the contact between people, which allowed a constant evolution and improvement in Early Modern cartography, even among those entities confronted by world hegemony.

Obviously, the information circuits that I will address were not created by spontaneous generation at the beginning of the sixteenth century, but they took root vigorously in medieval times. For instance, Portugal welcomed a significant number of Italians from the thirteenth century onwards. The flow of people occurred also in the other direction, with many Portuguese students, clergy and nobility being hosted in the main Italian universities and cultural centres (Cattaneo). ${ }^{8}$ This interchange was also reflected in the fifteenth century cartography produced in the Italian peninsula. Good examples of this were the chart of Grazioso Benincasa (c. 1468) ${ }^{9}$ and the Cornaro Atlas (c. 1489), which included Portuguese data in their depictions (Relaño, 2002).

Also, in the fifteenth century, Henry the Navigator became interested in the cartography being produced in the Balearic Islands, which had already become a well-known production centre thanks to works of the calibre of the Atlas Catalán. At some undetermined point in the first third of the century, Henry the Navigator took on the services of Jahuda Cresques - also known as Jacome de Mallorcathe main exponent of Majorcan cartography at that time, for which he paid a "high price" (García, 2015, p. 38) ${ }^{10}$ But the cost was nothing compared to the benefit, since Jacome de Mallorca's priceless nautical knowledge was integrated into the Portuguese cartographic information corpus.

With the end of the fifteenth century and the beginning of the sixteenth, the Iberian scenario underwent 
profound transformations. The explosion of Castilian nautical cartography only took place after the first voyage of Columbus. By that moment, Portugal had already explored the Atlantic archipelagos (apart from the Canary Islands) and had sailed the whole west coast of Africa, rounding the Cape of Good Hope. Meanwhile, Castile had been busy enough solving its internal problems and emerging victorious in the dispute over the control of the Canary Islands. The new set-up resulting from the sudden appearance of America made something very clear to the Castilians: they had a lot to learn from their Iberian neighbours. Simultaneously, thousands of kilometres east, Genoa, Venice, Florence, Ferrara and some other cities watched what the great nautical powers of the moment produced expectantly, thirsty for knowledge about the New Worlds being discovered.

The aim of this study is to identify and analyse several historical cases that show the interactions between the cartographic knowledge corpus of Portugal, Spain and Italian cities between 1500 and 1580 . In this way it will be possible to "name, shame and fame" some of the characters of a complex process that is known to have occurred, but whose true scope is almost ignored.

The contacts through which the circulation of cartographic information took place adopted different procedures that I have divided into two general categories, according to the nature of the exchange: illicit appropriations and "brain drain." The first category has the most varied examples in terms of sophistication: from the subtle art of espionage, to the theft of nautical charts by misusing institutional authority. The second category, in turn, orbits around a benign exchange of cartographic knowledge, resulting from the "hiring" of foreigners to improve the performance of the contracting party. This method could only be turned against the employer if the employee betrayed his trust by leaking sensitive information to rival powers, which would also involve a transfer of information. As will be seen further on, suspicion of an eventuality of this nature led to the implementation of certain conditions in the hiring of foreigners. However, these conditions in no way stopped the flow of people and information that was so highly beneficial to both parties involved.

\section{ILLICIT APPROPRIATIONS}

Starting with the most elegant procedures, let us immerse ourselves in the Early Modern spy world. Espionage in the broadest sense of the term was nothing new for the sixteenth century, ${ }^{11}$ but considering strictly cartography, there are some cases that are especially striking. I will begin clarifying the most famous of them all: that of Alberto Cantino and the planisphere that was sent to Ercole D'Este, Duke of Ferrara, in 1502 (Fig. 1). ${ }^{12}$ On some undetermined date between 1500 and 1501, Ercole D'Este sent Alberto Cantino as ambassador to Lisbon. There, for almost two years, the estense plenipotentiary was integrated into the deepest circles of the Lisbon court: he attended ceremonies of the calibre of the appointment of Vasco da Gama as admiral in privileged positions, was invited by D. Manuel I himself to his Sintra palace and was very aware of all the news that circulated in the capital of the Portuguese kingdom (Moreno Madrid, 2019b). ${ }^{13}$ So Cantino was not a typical spy, or at least did not perform his secret work in the terms it is understood today. He was another diplomat in the effervescent Lisbon of the early sixteenth century, who as such, communicated to his lord as much news as he was able to bring together. ${ }^{14}$ If he had really been entrusted with some kind of "secret mission" related to the cartographic field is impossible to know. In a sense, as will be shown, the line between diplomacy and espionage could be very thin in some cases.

But on November 19, 1502, Cantino wrote a letter informing the Duke that he had obtained a Portuguese map (Sánchez, 2013, p. 81) in which all the new discov-

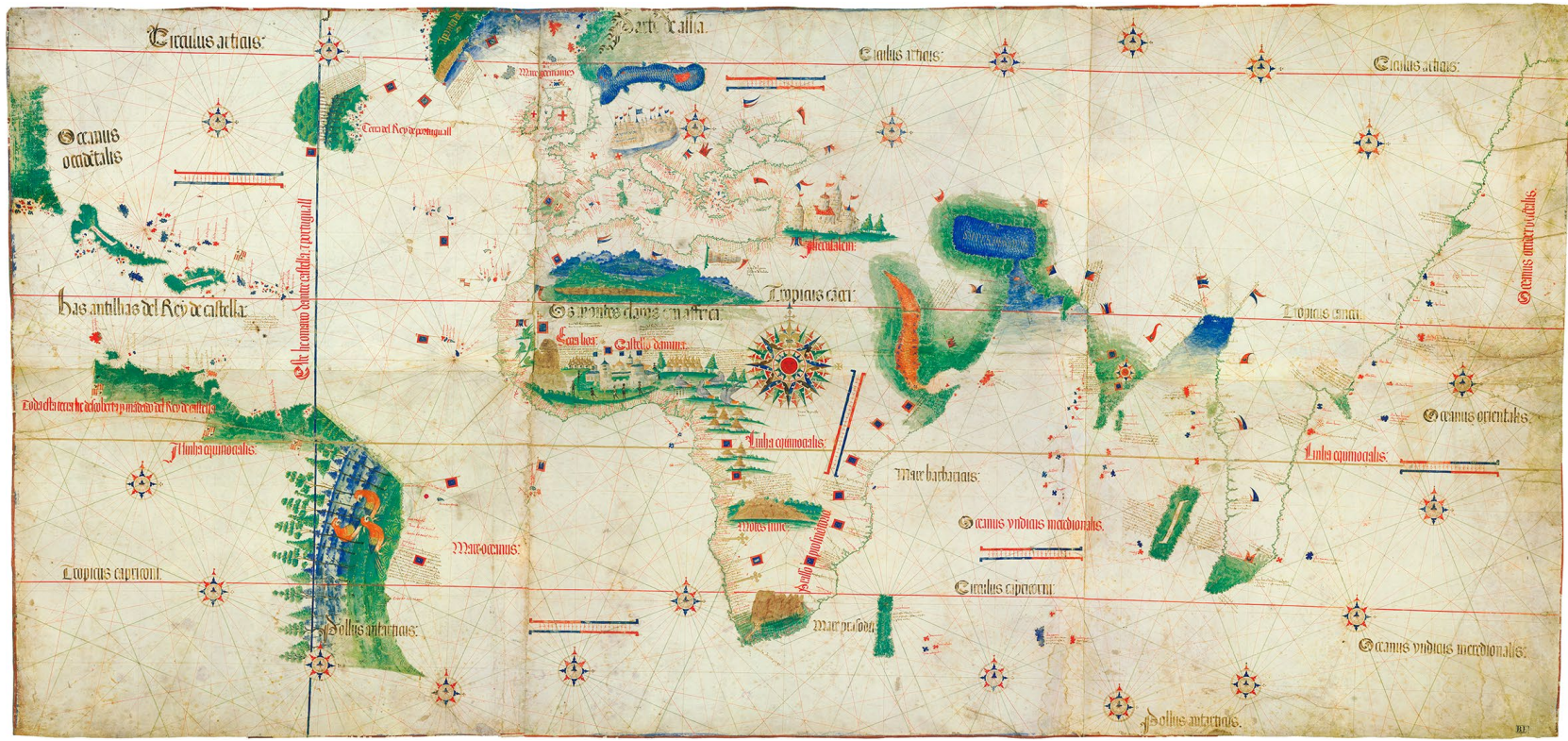

Figure I. The Cantino planisphere, anonymous, 1502. Estense Library (Módena). 
eries were collected. Nothing is known for sure about the method of obtaining the map other than that Cantino disbursed 12 gold ducats for it (Cortesão and Mota, 1987, p. 7). ${ }^{15}$ But the point here is that a spectacular reservoir of cartographic information travelled from Lisbon to Ferrara, and remained guarded in a tremendously active court (in terms of circulation of knowledge). ${ }^{16}$ As such, the novelties presented by the document obtained by Alberto Cantino soon dispersed throughout the Italian peninsula, as the so-called Caverio Planisphere (1504/1505) proves (McIntosh, 2015). ${ }^{17}$

Cantino's case is not the only one in which diplomacy and espionage intersect and blur their boundaries in Lisbon at the beginning of the sixteenth century. Between 1501 and 1502, Angelo Trevisan, as secretary of the Venetian ambassador to Spain and Portugal Domenico Pisani, ${ }^{18}$ wrote four letters to his friend and chronicler Domenico Malipiero, of whom he had also been secretary (Caracciolo Aricò, 1992). The content of these letters was nothing less than a report of the first three voyages of Columbus, which became a first-hand source on the New World for Venice (Bellini, 2008, p. 162). But Trevisan wanted more, and as a Venetian he was especially interested in what was happening in the brand-new Portuguese India. ${ }^{19}$ In August 1501, he wrote to Malipiero informing him that he had an envoy in Lisbon that he hoped would bring news about the Portuguese discoveries. He added that he would love to see this information on a map, but reported that the security measures adopted by the Portuguese institutions made such a task very difficult (Brotton, 2014, pp. 277278). Resignation gave way to optimism when, shortly after, Trevisan wrote again, notifying Malipiero that he had in his possession Portuguese cartographic documents of great value that showed the lands "beyond Calcutta", and that Malipiero could see them when he returned to Venice (Brotton, 2014, p. 278). But neither the maps nor reference to them reappear in the sources. Unlike Cantino's story, it is impossible to verify if the documents that Trevisan had in his possession reached the Serenissima, and if from there they were also disseminated to other corners of present-day Italy, so this Portuguese-Venetian contact remains a fascinating loose end.

Castile also knew how to play this game. It is evident in a Real Disposición of c. 1575 addressed to the ambassador in Portugal, who according to the date must be Juan de Silva. The document is a repertoire of several matters on which the diplomat should collect information "secretly" and with "concealment". The first of them refers to the need to give word immediately if from Portugal "people and ships were sent to go to discover or populate some islands or provinces of the Indies within the limits and demarcation of their Majesty", which would immediately trigger a situation extremely tense among the Iberian crowns. The second orders Juan de Silva to apprise himself of Portuguese rutters and travel reports. But it is the third instruction that directly alludes to nautical charts:

It is understood that the new charts made in Portugal artificially shorten and narrow the trips and navigation that the Portuguese make to their territories in the Indies, because they misunderstand the limits of their demarcation, and lengthen the one made of Spain. It is therefore appropriate that, with the concealment that the case calls for, you should try to understand everything related to this issue, and always carry out this work with the industry that is required. ${ }^{20}$

Undoubtedly, Juan de Silva had among his duties to find out everything possible about the Portuguese charts that were being produced at that time, with the goal of clarifying the precision with which the line of demarcation of the Indian territories had been drawn.

Unfortunately, for most of his predecessors there are no such precise documents in cartographic matters. Still, study of the documentation around them suggests that they would have carried out very similar activities. Let us go back to the 1530s, when Luis Sarmiento de Mendoza was responsible for safeguarding Portuguese-Castilian relations as ambassador. Unexpectedly, while performing his diplomatic work in the city of Évora, he was involved in a thorny issue that could incur in another variant of illicit appropriation: the theft of nautical charts by misusing institutional authority.

It all began with the letter he wrote to the Emperor on July 15, 1536. Its first part is not of special interest for this study since it refers to the expedition commanded by Aires de Acunha to Maranhão. ${ }^{21}$ However, it is an interesting fragment for appreciating the skills of Sarmiento de Mendoza in obtaining information because, despite warning on several occasions of the secrecy that surrounded this expedition, he was able to compile a detailed account for Charles V. Besides, the allusion to a pilot bringing some cartas could induce us to think that they could be nautical charts, but the context seems to indicate that he was referring to "letters." But the second part seems to have much more to say in relation to the issue discussed in this paper. In it, Sarmiento de Mendoza reports his meeting in Évora with Andrés de Urdaneta, one of the survivors of the catastrophic expedition of García Jofre de Loaysa. Outraged, the Biscayan explorer complained to Sarmiento de Mendoza that he:

has brought letters and a book of things from there [Maluco], given to him by a Castilian, Fernando de la Torre, who was the captain of the Castilians who had remained there, and these letters that he brought from this Hernan [do] [are] for His Majesty. In Lisbon, an officer of the [Portuguese] King took the letters and the book from him, and they would not give them to him..$^{22}$

Then, Urdaneta tells Sarmiento de Mendoza that he "knows all that was written in the letters and the books, as a man who has been there", and, intelligently, the ambassador identifies Urdaneta as a human reservoir of information, prioritizing his return to Spain to inform the King. Trusting Urdaneta's memory, Sarmiento de Mendoza decided not to take action to recover the documentation, although Urdaneta, aware of its value, encouraged him to do so. It is hard to think that in an expedition of the impor- 
tance of that of Jofre de Loaysa no cartographic testimony will be left, and that this testimony was not of the highest priority among the documents that should return to Spain. Indeed, following the sources ${ }^{23}$ Fernández de Navarrete points out the existence of some "papers in which the islands of Maluco, Banda and others were settled" among the documentation that was stolen from Urdaneta and Del Poyo (Fernández de Navarrete, 1837, pp. 159-160). There is no doubt that these "papeles" would incorporate interesting news about the geographical knowledge of those distant lands, nor is there any doubt that the cartographic loot would have aroused great interest in Lisbon.

But the case of the papers of Urdaneta and Del Poyo is not the only one in which institutional powers gave free rein to their authority to obtain cartographic information. On November 1, 1556, the Castilian bureaucratic machinery was launched to prepare a visita for Doctor Vázquez, from the Consejo de Indias, to the Casa de la Contratación. ${ }^{24}$ The visita, paid with a salary of six ducats per day, ${ }^{25}$ resulted in the firing of Francisco Duarte Jr.- who had replaced his father the previous year-and of the treasurer Francisco Tello (Donoso Anes, 1996, p. 74). Among the abundant documentation produced by the visita of Doctor Vázquez there is a Real Cédula dated February 14, 1557, which closes in stating:

I have been informed that in the possession of the fiscal Fran[cis]co Mejia there is a nautical chart and an astrolabe that was taken from a Portuguese, which he says are ours. And that is why it is good that they are brought to our Consejo de Indias to be in it; I command you to provide as it is brought later. ${ }^{26}$

It seems that the Doctor fulfilled his mission, since neither the letter nor the astrolabe is mentioned again in the sources. According to the document, the prosecutor accused the Portuguese of having possession of Castilian nautical tools, and the king ordered Juan Vázquez to requisition them and take them to the Council of the Indies. Whether or not Mejía's accusation is true is impossible to know, but in either of the two potential scenarios a very interesting situation arises. If the Portuguese had stolen the chart, the information contained in it could have circulated to Portuguese territory, and the Spanish authorities would have requisitioned it justifiably; if, on the other hand, it was a Portuguese chart belonging to him, the confiscation was not justified at all and was in response to an illegitimate procedure on the part of the Castilian institutions. ${ }^{27}$ The truth is that this second option does not seem unlikely at all, and it would make sense as a surreptitious way to collect foreign cartographic information.

A similar case occurred in 1513, when it was reported that the Casa de la Contratación had requisitioned all the "original deeds" carried by a Portuguese caravel that had come from the island of San Juan. By Real Cédula on December 28, 1513, it was ordered that such documents be sent to the court "with the first messenger" that arrived. ${ }^{28}$ Although it is true that the presence of cartographic documents is not specified among those requisitioned, it is very likely that there were some. On the other hand, I cannot fail to mention that in the same Real Cédula as the above, King Ferdinand instigated the recruitment for the Casa de la Contratación of the Portuguese pilots who appeared in Seville (Collins, 2014, n. 7). It is interesting how in the same document are contained two completely different methods to get hold of foreign information: to pinch documents, or to hire pilots and put their knowledge to work in an "honest" way.

Returning to the Spanish ambassadors in Lisbon, one should note the action of Cristóbal de Moura, the last to occupy the post before the Iberian Union. Among the many missions entrusted to him by Philip II, I will concentrate my attention on only one, which clearly involved obtaining cartographic information. It happened throughout the year 1579 and was directly related to the voyage being carried out by the English corsair Francis Drake. According to Pedro Sarmiento de Gamboa, Drake carried with him a nautical chart he had obtained in Lisbon for the hefty price of eight hundred ducats (García Redondo and Varela, 2013, p. 442). When this news reached Spain, it set off the alarms of the Consejo de Indias. Its president, Antonio de Padilla, wrote a letter to Philip II on 31 August 1579 , in which he reports that Drake, before setting sail from Plymouth, had spent several days in Lisbon, learning about navigation and obtaining a map that he would have used in his navigation. He then suggested that the monarch should write "immediately" to Gabriel de Zayas, the new secretary of the Consejo de Italia, so that he could write to Cristobal de Moura. Padilla's proposed mission for Moura was to get a copy of the map by contacting the cartographer responsible for providing it to Drake. Philip II must have agreed with Padilla's proposal, as he responded: "inform Zayas, so that a letter can be written at once" (Nuttall, 1914, p. 405).

An update of these instructions was transmitted to the ambassador in Lisbon by a Real Cédula dated November 24, 1579, in response to an earlier letter from Moura himself. The first part of the letter summarizes Drake's passage through the Strait of Magellan and his travels along the coast of Spanish America. Moura is then instructed to inform the King of Portugal that Drake's return route would probably be through the Moluccas, so it would be advisable that preventive measures be taken in that area. Obviously, it is not a selfless warning. As the document states, once the corsair was arrested by the Portuguese forces, the Spanish Crown had in mind to recover what had been looted on American lands. ${ }^{29}$ The second part alludes directly to the mission conceived by Padilla, and includes some modifications that reflect the fact that Spanish intelligence had been working on the "Drake case." For example, the August letter spoke of Drake's stay in Lisbon of "a few days", while this letter refers to a period of "almost two years." Similarly, in Padilla's letter it is mentioned that the English corsair was in Lisbon "endeavouring to ascertain the navigation route of the Portuguese from East India hither", while the November one says that he was "learning about navigation in the South Sea and the entrance to the Strait of Magellan with intelligent and experienced people." ${ }^{30}$ 
But Moura's assignment, a full-blown cartographic espionage mission in the Portuguese capital, remained unchanged. Once again, the idea of carrying out the task "with all care and industry", or what is the same, in the most absolute secrecy, is emphasized. Nevertheless, everything points to the fact that the ambassador did not succeed in his mission, since a year later Bernardino de Mendoza, holder of an equivalent post in London, communicated to Philip II his displeasure at not having been able to see the aforementioned chart, which Drake presented to Elizabeth I (García Redondo and Varela, 2013, p. 442).

Guido de Lavezaris seems to have had more success in these matters in one of the episodes he relates in his letters, written during his stay in the Philippines. Lavezaris was born in 1512 into a Genoese family of booksellers (Wagner, 1994, p. 380), which enabled him to take refuge in their clientele networks and to climb through the colonial administration to the post of Governor of the Philippines (Rueda Ramírez, 2002, p. 49). After an eventful return to New Spain after participating in the expedition of Ruy López de Villalobos (1542), he embarked once again on the expedition of Miguel López de Legazpi (1564), remaining in the Philippine archipelago as Tesorero de la Real Hacienda until 1572, when he was promoted to Governor of the islands on the occasion of Legazpi's death. The aforementioned letters he sent to Spain are a rich source of information for studying what was happening in Southeast Asia at the time. Especially interesting for this study are the last lines of the one sent on July 25, 1567, which read (Blair and Robertson, 1906, p. 212): ${ }^{31}$

In the belief that I was doing your Majesty a service, I endeavoured to get the loan of a map and navigation chart from the Portuguese, and quickly had a portion that falls within the Castilian demarcation copied from it as well as certain remarks made by one of our pilots. I enclose it herewith, and if your Majesty be so pleased the cosmographers may see by it the position of the lands and islands now newly discovered.

Before communicating the obtaining and sending of the documents, Lavezaris informed the monarch of the movements of the Portuguese in Tidore, Gilolo and Ternate, warning of the stratagems they were using to continue getting the most of the islands, and of their intentions to send reinforcements to attack the Spanish enclaves (Blair and Robertson, 1906, pp. 210-211). The Moluccas area, despite the agreements reached in Zaragoza in 1529, continued to be a hot spot for Portugal and Spain, with skirmishes taking place from time to time, as can be seen from the Governor's account. Thus, in a kind of guerrilla context, Lavezaris managed to pinch a map and a nautical chart from the Portuguese, sending them to Spain as quickly as possible to be analysed. There they would be received with great interest, since the question of the Moluccas was also in full swing in Madrid. In fact, the protagonist of the following case could have been one of the cosmographers who had access in Spain to the material sent by Lavezaris.
I am referring to Juan Bautista Gesio, a Neapolitan integrated in the Madrid court since 1565 (García Barreno, 2020, p. 11). In 1569 he travelled to Lisbon with ambassador Juan de Borja to obtain various Portuguese nautical documents, including, of course, some nautical charts (Goodman, 1992, p. 61). On his return in 1573, the cartographic loot obtained was reviewed by Antonio Gracián, Juan de Herrera and the Count of Chinchón. The large amount of confidential information that he had collected in the neighbouring country led Gesio to remain in Madrid (Portuondo, 2009, p. 187), holding the position of Cosmógrafo de Palacio after the death of the Maestro Esquivel (Esteban Piñeiro, 1999, p. 125). In his mission Gesio had been assisted by a Portuguese cosmographer named Luis Jorge de Barbuda, who was interested in entering the service of Philip II. Arrested for two years for treason in his native land (Albuquerque, 1974, p. 209), it was not until 1579 that the Portuguese entered the service of the Castilian monarch with the help of Gesio (Goodman, 1992, p. 62). As Albuquerque points out (1974, p. 209), Gesio extracted from Lisbon "a large number of maps, relations, rutters and geographical and historical descriptions that were destined for the Escorial Library." The booty was placed at the disposal of Juan López de Velasco, who in 1574 published a report on the materials that the Neapolitan cosmographer had stolen in Lisbon, ${ }^{32}$ recommending that at least part of them should be copied and moved to the Monasterio de El Escorial, which, in the end, did not happen (Portuondo, 2009, p. 187). There is no doubt that the cartographic documents stolen by Gesio served not only to reinforce the Spanish position on the Moluccas issue, but also to enrich its cartographic corpus in general.

So far I have treated the sort of diplomats or "politicians" with solid spy instincts, who (when situation became dangerous) always had a safety net because of their institutional position. But what happened to those who jumped into the void without that parachute?

In 1503 Sancho de Matienzo, first treasurer of the Casa de la Contratación, granted Juan de la Cosa 25 gold ducats for his services on a mission that the sailor had carried out in August of that same year in Lisbon (Moreno Madrid, 2019a, p. 104). The few data that exist on the event suggest that the objective was espionage. Juan de la Cosa was captured and imprisoned, and Queen Elizabeth of Castile had to intercede on his behalf to save him from an uncertain destiny. In addition, of the 25 ducats mentioned, 7 were given as payment for two hydrographic charts that La Cosa had bought in the Portuguese capital (Moreno Madrid, 2019a, p. 105). In a similar way to the case of the Cantino planisphere, there is documentary evidence that the hydrographic charts that La Cosa obtained in Lisbon arrived at their destination and enriched the corpus of cartographic information that had begun to be forged in the brand-new Casa de la Contratación of Seville.

Seven years later, King Manuel I of Portugal tried to get payback in the same coin for the intrusion of Juan de la Cosa. On November 3, 1510, Alonso Álvarez, Por- 
tuguese, was imprisoned in Seville. ${ }^{33}$ He had been sent by his monarch to find out about the Castilian discoveries and try to win over the pilot Juan Rodríguez Mafra (Fernández Vial, 2011, pp. 78-79). The situation between Castile and Portugal became tense, and on December 18, 1510, the Officers of the Casa de la Contratación indicate that Alonso de la Puente would be instructed for mediating with King Manuel I; for this purpose, he would carry a report of what had happened until that moment. ${ }^{34}$ But the unmasking of a simple spy was not to be the trigger for the latent conflicts between Castile and Portugal. On December 20, the good treatment that the prisoner was receiving was emphasized, ${ }^{35}$ and at some point during the first months of 1511 he had to be released, since on May 22 of that year Sancho de Matienzo received a Real Cédula to pay Lorenzo Pinelo, alguacil of the Casa de la Contratación, the sum of ten thousand maravedies for the time that Alonso Álvarez had spent captive in the Casa. ${ }^{36}$

The 1510s were also marked by the case of a spy in Portugal at the service of the Casa de la Contratación, paid by the King Ferdinand. This is evidenced by a Real Cédula of October 24, 1516 in which the Officers of the Casa are induced to learn "secretly" about the future intentions of Francisco de Aguiar, resident in Portugal, to which the sovereign of Aragon was disbursing the trifling sum of 15,000 maravedis annually for offering useful information to the Casa de la Contratación. The Cédula seems the result of a certain period of time without news of the agent, specifying that his salary was not to be paid until further notice. ${ }^{37}$

Obviously, documentary support for cases of minor espionage is very limited. Of the three cases presented here, only one grants evidence of stolen cartographic material, while the other two just open the door to speculation. The truth is that, although they did not manage to obtain cartographic documents, it is undeniable that both Alonso Álvarez and Francisco de Aguiar were very interested in everything that surrounded the maritime expansion of their espionage destinations. In the case of the former, his confession proves it, since he was interested in winning Mafra over. Meanwhile, the second one worked for the Casa de la Contratación. According to these interests, it does not seem risky to speculate that cartographic information could be in their sights.

Particularly fascinating is the following case, which began as an espionage mission and ended up in what might be called a bona fide exchange. In addition, the episode starred and was told by, in his own handwriting, one of the most famous cosmographers of the Casa de la Contratación. Amid great confusion about the behaviour of the nautical compass in New Spain, Alonso de Santa Cruz decided to go to Lisbon to increase his knowledge in this area and in many others related to East India. ${ }^{38}$ Once there, his goal was to speak with João de Castro, one of the great Portuguese men of science of the sixteenth century and Governor of Portuguese India between 1545 and 1548. Let us see what Alonso de Santa Cruz has to say about their interview:
Don Joan de Castro [was] a very learned and very curious gentleman who had gone to India many times, and had made the description of it, putting in writing and in painting the ports, rivers and streams that are at the entrance and in the mainland. He also compiled stories of the remarkable things of the lands and places that are there. And he did the same with the whole Red Sea, because he was everywhere until Suez, which is the northernmost of the said sea. And at the end of this sea is where the Grand Turk has all his galleys, with which he infests all those seas. He gave me the transfer of these books with a warning not to show them to any person in Portugal, in order that the memory of such illustrious and curious works would not be lost. ${ }^{39}$

Alonso de Santa Cruz's story is so thorough that it seems to leave little room for additional explanations, but there are two things that should be examined. The first is that when Alonso de Santa Cruz talks about "paintings" he obviously refers to cartographic documents. Keeping this in mind, it is more than likely that were some nautical charts in the documentary lot that D. João de Castro gave him. The second point is interesting in terms of history of science. If the words of Santa Cruz are understood to be true,${ }^{40}$ the interview between him and D. João de Castro is a clear example of scientific interchange between colleagues. Leaving aside kingdom rivalries, these two men sit down serenely to talk about science. And when the conversation ended, D. João de Castro decided that the best way to safeguard his work before his departure to India was to entrust it to an equal, whatever his "nationality." From the warning he gives to Santa Cruz about not showing the documents to any Portuguese, it follows that D. João de Castro was very aware that he was committing treason. Still, he preferred to take the risk and make sure that his life's work ended up in good hands. Bear in mind that this seemingly modern episode was happening in the mid-sixteenth century.

\section{BRAIN DRAIN}

As was pointed out in the introduction, at the beginning of the sixteenth century Castile had much to learn from its Iberian neighbours. At that time, learning was a race whose goal was imperial domination, so it was imperative to learn fast and well. Hiring foreign talent and thus taking advantage of the Early Modern brain drain was one of the most frequently-exploited ways to get ahead in the race for nautical knowledge.

It is obvious that hiring an excellent cartographer, cosmographer or mathematician, whatever their "nationality", meant greatly enriching the production of nautical knowledge wherever they were employed. In fact, the knowledge and skills he brought thanks to his learning in another environment was a plus that made all the difference. This meant, in the case of Portugal and Spain, that they had to grant foreigners full access to their precious centres of calculation and to their ships (and therefore, access to their corpus of cartographic information). On the 
one hand, there was no doubt that this policy could be tremendously beneficial to the imperial structure; on the other hand, the shadow of suspicion never quite disappeared.

Starting with Portugal, it is difficult to clarify the number of Spaniards or Italians who held important positions in the Armazéns de Guine e India at the beginning of the sixteenth century. ${ }^{41}$ Between 1503 and 1526, the pilots Pero Anes, Gonçalo Alvares, João de Lisboa and Fernando Afonso were appointed to the positions of patrão-mor and piloto-mor (Mota, 1969, p. 8); although their nationality is not specified, their names suggest that the four were Portuguese. Similarly, the post of cosmografo-mor, officially established in 1547, was only occupied by Portuguese cosmographers during the sixteenth century: Pedro Nunes $(1529 / 1547-1580)^{42}$, Tomás de Orta (1580-1591) and João Baptista Lavanha (1591-1608). One should not lose sight of the fact that Portugal began the sixteenth century at the forefront of the nautical field, so its need to hire foreigners would not be so pressing.

Meanwhile, the Casa de la Contratación in Seville has been the subject of numerous studies, ${ }^{43}$ providing us with a much better list of foreigners who worked there. In 1508 the Florentine Américo Vespucio was named Piloto Mayor, a position he held until his death in 1512, when he was succeeded by João Dias de Solis (or Juan Díaz de Solís), whose birthplace is still open to debate (Sánchez, 2010 , p. 615), although everything points to the fact that he was Portuguese. Be that as it may, what is interesting for us is that he began his maritime career in the service of the crown of Portugal, later moving to Castile. ${ }^{44}$ Sebastian Cabot, Venetian, succeeded Solis in 1518 (Sánchez, 2010, p. 615), leaving the position vacant in 1526 and reassuming it in 1532 (Collins, 2013, p. 26). Giovanni Vespucci, Florentine and nephew of Américo, played an important role in the Casa due to the constant absences of Sebastian Cabot (Sánchez, 2010, p. 616). After Cabot, and until the end of the sixteenth century, only Castilians held the post: Alonso de Chaves, from Seville (1552-1575), and Rodrigo Zamorano, from Valladolid (1575-1613) (Pulido Rubio, 1950, p. 981). All of these figures brought their experience and knowledge of foreign shipping to the Casa de la Contratación, and with the exception of Cabot, who entered the service of England in 1547, ${ }^{45}$ they do not seem to have spread what they learned in the service of the Spanish crown.

There was also no hesitation in placing foreigners in charge of producing the cartographic documents, giving them access to the ins and outs of the Casa. The most famous of the foreigners who carried out this work was probably Diogo Ribeiro, Portuguese, appointed cosmographer of the Sevillian institution in 1523 (Sánchez, 2010, p. 617). Another illustrious example was Francisco Faleiro, who arrived as part of the entourage of men of science that accompanied Magellan to Seville. ${ }^{46} \mathrm{He}$ ended up staying in the city of Seville, putting his cosmographic knowledge at the service of the Casa. ${ }^{47}$

Lesser known is the name of Gaspar Rebelo, Ribeiro's and Faleiro's compatriot, who tried to enter the service of the Casa de la Contratación in the 1530s as a cosmographer. On February 10, 1535, the Council of the Indies communicated to the Officers of the Casa de la Contratación its offer to "make some new instruments of the art of navigation, necessary for the navigation of our Indies." 48 In order to know if the promised instruments were worthwhile, they had to be tested by some of the authorities in the discipline working in the Casa, and this was ordered by the Council of the Indies on June 16, 1535. The designated reviewers were Fernando Colón, Sebastian Cabot, Francisco Falero, Alonso de Santa Cruz, and "other people who you [Colón, Cabot, Falero and Santa Cruz] think have experience in these things." ${ }^{49}$ Moreover, at the end of the instructions it was explained that "after the above-mentioned is done, the said instruments will be returned to the said Gaspar Rebelo", ${ }^{50}$ to avoid giving rise to a situation similar to that of Mejía.

The examination must have yielded satisfactory results, since on 23 July 1537 Rebelo was authorized by a Real Cédula to make charts and instruments. ${ }^{51} \mathrm{He}$ was unable to begin work at the Casa, though, as Cabot denied him permission, alluding to his Portuguese nationality (Collins, 2013, p. 26). The refusal, however, could have more to do with Cabot's own personal interests and his desire to maintain, along with Gutiérrez, a monopoly on nautical instruments and charts produced at the Casa (Collins, 2013, p. 27). ${ }^{52}$ Frustrated, Rebelo explained the situation to the monarch. Charles V must have been interested in keeping Rebelo in his service, since on May 13, 1538 he addressed a Real Cédula (which restated the content of that of July 23, 1537) to Sebastian Cabot, ordering the Piloto Mayor to allow the Portuguese cosmographer to carry out his work. And in case Cabot was tempted to disobey, he forced him to show both documents to the Officers of the Casa, with the following threat.: "[...] you and they will respect the Cédula and comply with it in everything [...], under penalty of our mercy and ten thousand maravedíes for our Cámara." 53

After the king's warning, Gaspar Rebelo should have been able to carry out his work without issues. But the truth is that on June 26 of the same year he was given a call to action for not having finished on time "certain instruments and charts of navigation" that Francisco de Camargo had commissioned from him ${ }^{54}$ probably for the expedition to the Strait of Magellan that would take place a year later. ${ }^{55}$ According to Camargo, Rebelo had used the ban on work that Cabot had imposed on him as an excuse, to which the monarch responded that he should finish the instruments and charts "without making any excuse or delay", and ought to ignore Cabot's instruction. To reinforce the gravity of his order, he warned that the Officers of the Casa would monitor compliance. ${ }^{56}$ As of this date, I have not been able to locate more information about Gaspar Rebelo in the sources. He might have continued to work at the Casa without any other incidents involving Cabot or his work commitments. Moreover, there is no evidence that Rebelo's loyalty to the Spanish crown was ever betrayed, which makes this case a good example of such a benign and mutually beneficial exchange.

The documents about a certain Andrés Fraile - or Freire - point out in other direction. On December 16, 1563 
a Real Disposición appeared announcing that Sancho Gutiérrez had informed the Consejo de Indias that there was a chart maker from Lisbon in Seville, son of a cosmographer of the king of Portugal, "who made nautical charts that were stamped and sold publicly." ${ }^{\circ 7}$ When the authorities found out, they banned such activity, and Fraile took the opportunity to return to his family in Portugal. But sometime later he returned to Seville, getting married there to claim Castilian nationality and be able to work as a cosmographer in the Casa de la Contratación. Sancho Gutiérrez argued that the main concern was that Fraile had copied the Padrón of the Casa, or that he could do so in the future if he were allowed access to the institution; and once he had obtained this information, he could take it to Portugal. Faced with such a threat, the same Real Disposición ordered an investigation of the said Fraile, requisitioning the nautical charts in his possession if he was found guilty, and prohibiting him from making more in the future (Sandman, 2008, p. 35). Less than a month later, the matter remained unresolved. On January 10, 1564 a Carta Acordada from the Consejo de Indias to the Officers of the Casa de la Contratación appeared, reaffirming the orders given about Fraile. ${ }^{58}$

What is certain is that, observing the documents, Andrés Fraile seems to have moved cartographic information from Seville to Lisbon. However, the sentence "[...] now he [Fraile] has returned to that city [Seville], with the endorsement of Chaves, cosmographer, and has married there to make the said charts again, as a native of these Kingdoms" 59 made Collins (2019, p. 212) suspect that the story of Fraile was only a pretext used by Sancho Gutiérrez to attack Alonso de Chaves, his rival in that "battle" between cosmographers and pilots that took place in the Casa de la Contratación in the mid-sixteenth century. Given the intensity of the contest, this is a possibility to be considered. Whatever the case, the Fraile incident presents another interesting exchange, emblematic of the grey areas in knowledge acquisition. If, on the one hand, Fraile was indeed pilfering the cartographic information of the Casa, it would be a situation where the employee would have taken advantage of the employer's trust to steal sensitive information. If, on the other hand, it was a political ploy, Fraile would be another honest Portuguese cosmographer in the service of the Casa, who had been put into a very difficult situation because of his "nationality."

Without leaving Seville, let us move from the Casa de la Contratación to the city's docks, where the ships that crossed the Atlantic in the direction of America were prepared. Although the Casa was a complex institution that handled huge volumes of information, it was still based on a limited physical space that allowed for a considerable level of control over the documentation in its custody. But controlling sensitive information aboard a ship on the high seas was a completely different story. And on the ships that sailed the Carrera de Indias travelled cartographic information. Of course, each crew member's access to this information was different, just as their duties on the oceanic voyages were not the same. ${ }^{60}$

On a normal voyage, a ship would receive two nautical charts: one for the pilot and one for the boatswain.
These documents contained the most up-to-date information on the route to be taken, based on data collected on previous voyages (Sánchez, 2019, p. 36). Throughout the sixteenth century these valuable cognitive devices were given to numerous foreign pilots who made up the crews of the ships of the Carrera de Indias. Among these pilots, the majority were Portuguese (Collins, 2014, pp. 184185). ${ }^{61}$ Collins distinguishes two stages in the recruitment of Portuguese pilots by the Castilian crown during the sixteenth century: pre-1530 and post-1530. The first was marked by the need of the Castilian Crown to obtain Portuguese talent to strengthen its maritime enterprises, while the second was characterized by a lesser urgency in these recruitments, although they continued to occur (Collins, 2014, p. 182).

The measures taken in contracting foreign pilots perfectly reflect the dichotomy of theory and practice in the protection of cartographic knowledge, with constant concessions and restrictions throughout the sixteenth century. The relative ease with which Portuguese practitioners could be hired by the Castilian crown during the first three decades was interrupted by the instructions received by Sebastian Cabot on August 2, 1527, which stipulated that the pilots must be natives of Castile (Collins, 2014, p. 182). Exactly two decades later, a second instruction explained the conditions in which a foreigner could serve as a pilot. If he was single, he must have a naturalization letter before being examined; and if he was married, he and his wife must reside in Spain (Pulido Rubio, 1950, p. 58). On September 5, 1561 it was forbidden to examine any Portuguese citizen as a pilot, after these were accused of abusing their position to help compatriots travel to the Indies "camouflaged" as Galicians (Collins, 2014, p. 190). A further Real Cédula appeared on November 11, 1566, which stipulated that "the pilot must be a native of Spain, twenty-four years old, of good manners and who has sailed for six years to the Indies" (Pulido Rubio, 1950, p. 60).

However, if the need was pressing, it was always possible to make some exceptions. Especially illustrative is the case of Jacome Luis, a Portuguese pilot who had demonstrated enormous skill on the Rio de la Plata (Collins, 2019, p. 209). ${ }^{62}$ News of his expertise must have impressed Charles V, who on 12 September 1545 signed a Royal Charter granting him the position of "pilot of His Majesty, with twenty-five thousand maravedies of salary." ${ }^{\prime 3} \mathrm{He}$ was so concerned that Jacome Luis would enter the service of Portugal and not his own that he told the following to his representatives there: "Give him the hope that we will always remember him and make him happy in whatever way we can. And [...] do not let him leave that city to go to Portugal in any way, for you can see the inconvenience that would follow." 64

In 1574, similar exceptions were made for Antonio Barbudo and Gaspar Núñez, in view of the need to fill pilot positions in the New Spain fleet. ${ }^{65}$ On April 6, 1574, Felipe II ordered the Piloto Mayor to examine Antonio Barbudo, a resident of Santo Domingo de la Española, as a pilot, even though he was of "Portuguese nationality." Just a month later, a Real Cédula approved Gaspar Núñez, Portuguese, as a pilot in the 
Flota de Nueva España without his even being examined. ${ }^{67}$ Only in December of the following year would Gaspar Núñez pass his test, with the aid of another Real Cédula ${ }^{68}$

Foreign masters were subject to the same conditions as the pilots to be hired, and their situation also oscillated between moments of permissiveness and others of stringency. Here, too, exceptions were the order of the day. In 1540 Antonio López de Aguiar, owner of a galleon that went to the Rio de la Plata, had to write to the king in order to take on Jorge Gago, Portuguese, as a master. ${ }^{69}$ A year later, Melchor Díaz, also from Portugal, faced the same situation. ${ }^{70}$ The mistrust of the masters was justified in that they also played a key role in the oceanic voyages and had access to reserved information. Their position required them to be versed in the art of sailing and prepared to replace the pilot if necessary (Fernández-López, 2018, p. 46). It is logical, therefore, that one of the requirements demanded of them was to know how to mark the position of the ship on the nautical chart. ${ }^{71}$ All these qualities can be seen in the case of Vasco Afonso, a master's candidate who "had gone for sailor and pilot on ships that have gone to the Indies as a skilled and sufficient person." 72 Despite this, Cabot refused to examine him, citing his Portuguese nationality, but the situation was resolved exactly as Rebelo's had been: with the king forcing Cabot to examine Afonso by sending him a Real Cédula. ${ }^{73}$

But those who did not hold "positions of responsibility" could help cartographic information to circulate. One should not forget that before nautical education was institutionalised with the creation of the Cátedra de Arte de Navegar y Cosmografia (1552), pilots achieved this status by working as sailors (Pérez-Mallaína, 2002, p. 216), a period in which they were initiated in the knowledge of the nautical chart. This is proved by the request of Hernán Pérez Jarada, Alonso de Illescas and Cebrián de Caritate in 1538 , on behalf of the merchants of Seville, that the owners of ships be allowed to go aboard as masters, on the condition that they carry with them an "examined pilot and boatswain and two sailors who know how to mark the position of the ship on the nautical chart and take the height of the sun, to each of which the owner of the vessel must give six ducats extra." 74

With this scenario in mind, it is logical that there would be some concern when someone who had already sailed under one flag decided to change it for another. This is proved by the instruction received by Luis Sarmiento de Mendoza on July 24th 1540:

Item. You say that one of those who wants to go in that Armada [de Portugal] is called Pedro Alvin, a Castilian who has always sailed in our kingdoms and territories, and who has experience and plática about such a discovery. If it were possible, bring him back, making him understand that once here, given his ability, we will send him to be favoured and we will employ him in a trade where he can be exploited. And let it seem that this was not ordered from here. ${ }^{75}$

On the one hand, Alvin had sailed for the Castilian crown, so nautical charts that united Spain with the Indies could have passed through his hands; now in Lisbon, he wanted to sail the seas under the Portuguese flag and his king knew it. Alvin could leak information of all kinds, including cartographic. On the other hand, it is possible that he had already had some other nautical experience with the Portuguese, and the data that he could have collected would be tremendously valued by the Officers of the Casa de la Contratación.

The ship, therefore, once lost behind the horizon line, was a perfect space to steal, copy, manipulate or simply memorize cartographic information that was within the reach of a considerable number of crew members. However, for the period under review, I have found no evidence in the sources that this happened. The truth is that it should not surprise us, since most foreigners who put themselves at the service of another power would do so because of a lack of opportunities in their homeland. ${ }^{76}$ Sedition would not be among his plans, as it risked losing the advantages already gained. Apart from that, if one of these pilots, boatswains, masters or sailors was interested in pilfering cartographic information, he would carry out his work in the most furtive way possible, because the punishment that awaited him if he were discovered would not be gratifying at all. For these reasons, there may not have been many cases where the employee betrayed the trust of the employer, but it is also difficult to assume that no leakage of cartographic information took place on board the thousands of ships that plied the Spanish and Portuguese routes during the sixteenth century.

\section{CONCLUSION}

That the cartographic information produced by Spain and Portugal in the sixteenth century circulated far beyond the territorial limits of both empires should not be surprising. However, if the forcefulness of the measures adopted to stem this flow leads one to believe that effective control was achieved, it is interesting to descend into practice and individually analyse the multiple contacts that took place between Portugal, Spain and Italian cities with cartography as the focal point. Throughout this paper a wide variety of instances have been presented, which were classified according to the procedure through which the circulation of information was achieved. I have also attempted to contextualize these cases, so that the circumstances in which they occurred provide the appropriate framework for the understanding of each contact. These instances aspire to exemplify the proposed typologies of contact, being only a small sample of the total that would have taken place in the first eight decades of the sixteenth century. As is often the case when working with the circulation of sensitive information, sources are not as generous as one would like, and one must sometimes resign oneself to leaving loose ends and speculating more often than desired.

Among what has been called illicit appropriations, it is important to mark the differences between "official figures" and spies in the purest sense of the word, as it is understood today. The level of danger faced by Alberto Cantino, Juan de Silva, Cristobal de Moura, Guido de Lavezaris or Juan Bautista Gesio is not comparable to that faced by Juan de la Cosa, Alonso Alvarez or Francisco de Aguiar. It is true that both groups carried out "espionage work", 
but not under the same conditions. This also means that the level of secrecy of the missions carried out by the second group is greater, leaving a much less obvious trail in the sources. The theft of cartographic documents by means of institutional authority - as seen in the case of the papers of Macías del Poyo and Urdaneta, the nautical chart confiscated by Mejía, and the documents of the Portuguese caravel that arrived in Seville in 1513 - could be highly effective, and trying to stop this process could lead to greater complications, as Luis Sarmiento de Mendoza himself warned. Particularly interesting and refreshing among the cases analysed in this first section is that of Alonso de Santa Cruz, due to its peculiar resolution with the voluntary delivery of the documents by D. João de Castro.

The brain drain category is based on the need to hire the services of foreigners to boost maritime expansion. Nationality could raise some suspicions, which translated into special conditions of employment for those who were not native to a country. But, as Collins states for the case of the Portuguese who emigrated to Seville: "Nationality was not necessarily so much of a practical concern in working routes of the Carrera de Indias, but it served as a particularly useful political tool that could be wielded to protect the interests of those in power" (Collins, 2014, p. 192). According to the sources, it seems that the theft of cartographic information taking advantage of the hiring by a foreign power would be the exception, either in the centres of calculation or on ships, because those hired had much more to lose than to gain. Instead, the transmission of this information occurred naturally, through the recruitment itself and the subsequent incorporation of new knowledge into a different cartographic corpus.

This mosaic of cases in which cartographic information circulated freely raises a question: how does the Teoria do Sigilo fit into this scenario? Cartographic knowledge was among the most sensitive data, and yet it was in constant motion. What happened with information that was not subject to such exhaustive control? Probably, its dispersion was even more far-reaching. In the light of this, it seems unwarranted to continue using the Teoria do Sigilo as a reason to avoid clarifying certain historical or documentary problems.

As inflexible and tightly controlled as institutional theory would have us see information exchanges, knowing actual practices allows us to glimpse very clearly that no Real Cédula, Real Provisión or instruction was impregnable, and that the transmission of cartographic information escaped the restrictions of the imperial policies constantly, enriching the total cartographic corpus that illuminated maps and nautical charts all over the globe.

\section{ACKNOWLEDGEMENTS}

I would like to thank Henrique Leitão and Francisco Malta Romeiras for carefully reviewing the original text and for their comments and suggestions to improve it. I would also like to thank Šima Krtalić for revising my English text. The research leading to these results has received funding from the European Research Council (ERC) under the European Union's Horizon 2020 research and innovation programme (grant agreement No. 833438).

\section{NOTES}

1 It is important to note that this particular device was different from the maps of the time because it was built as a scientific instrument, whose ultimate purpose was to guide navigators on their journeys, and not to represent the world reliably. See Gaspar and Leitão (2018b, 2019).

2 The Armazéns de Guine e India in Lisbon and the Casa de la Contratación in Seville fit perfectly with the concept of centres of calculation coined by Bruno Latour in 1987. For a current approach to the concept see Jons (2011).

3 For this process applied to the Padrón Real see García Redondo (2018).

4 The Politica do sigilo has caused rivers of ink to flow. Jaime Cortesão's book "A política do sigilo nos descobrimentos" (1960) became, along with Diffie (1969), the standard text; but since then other interesting works have appeared rethinking the issue. See Harley (1988) and Domingues (1990). Most recently, Daniel Vecchio Alves (2018) published some historiographical reconsiderations on the topic.

5 One of the referees drew my attention to a very interesting "exception" to the Spanish institutions' desire to keep cartographic documentation in secret. It has to do with the legal purchase and sale of specific maps and instruments within the scope of the Casa de la Contratación. Indeed, in the Book IX, Title XXIII, Law III of the Recopilación de Leyes de Indias (1841, v. 3, p. 301 ), one can read that the Piloto Mayor can make "nautical charts and instruments for himself, or to sell them outside the city of Seville; and he can also make and sell maps and globes, and the other instruments that the masters and pilots do not use in their navigation [“...; y permitimos que los pueda hacer para sí o para vender fuera de la ciudad de Sevilla; y asimismo que pueda hacer y vender mapas y globos, y los otros instrumentos de que los maestres y pilotos no usan en su navegación"]. Another concrete example of the "holes" that Politica do Sigilo left along the way.

6 "Spanish cartography", "Portuguese cartography" and "Italian cartography" for the sixteenth century are necessary and very useful historiographic categories for a simple approach to the cartographic production in each of these centres. However, throughout the nineteenth century and much of the twentieth, they were used with a certain nationalistic flavour. As a consequence, it is possible to find map studies dedicated exclusively to clarify the identity of the producing "nation", seeking to proudly isolate the cartographic document from the rest of the world for its exceptional characteristics. A good example of this was the fierce debate around the authorship of the Cantino Planisphere. Vittorio Bellio, Derby d'Orville, Jean Denucé, E.L. Stevenson, Paolo Revelli, Roberto Levillier, Duarte Leite and finally Armando Cortesão were the main names that crossed swords to label the map as Portuguese or Italian. In: Mota and Cortesão, 1987. In addition to investigating the origin of the cartographic document, these studies concentrated their efforts on carefully analysing everything that was on the map -toponymic and stylistic studies, for instance-, sometimes forgetting what was around its production. All these approaches are of great interest, and largely responsible for laying the foundations of current cartographic studies. Nevertheless, recent historiography has identified other problems in cartography that help enormously to unravel the construction processes of Early Modern maps and nautical charts: scientific problems. See, among many others works of the authors: Gaspar (2011); Leitão and Gaspar (2014); Gaspar and Leitão (2018a, 2018b, 2019). For new reflections on the concept of space, see Padrón (2004). Or for dynamics of information circulation, see Brendecke (2016, pp. 155-217); García Redondo (2018) and Sandman (2008).

7 On the relevance of the geographical factor in the production and circulation of knowledge, see Livingstone (2003).

8 For an in-depth study of the Italian interest in Portuguese discoveries see Radulet (1991).

9 For an in-depth study of the chart see Caraci (1950, pp. 18-31). 
10 See Sánchez (2013, pp. 54-56)

11 From July 2018 until July 2019 the General Archive of Simancas organized a temporary exhibition entitled "Espías: servicios secretos y escritura cifrada en la Monarquía Hispánica.” For a good approach to the matter of espionage in Castile during the sixteenth and seventeenth centuries see the catalog of the exhibition: Departamento de Difusión del AGS (2018).

12 The literature on this event is unapproachable. "Portugaliae Monumenta Cartographica", by Armando Cortesão and Avelino Teixeira da Mota (1960; 1987 revised edition) became the standard text. On the political side of the map see Varela (1998). Among recent historiography stand out: Milano (2004), Fernandes (2003) and Gaspar (2012).

13 These events can be read in the letters Cantino sent to Ercole D'Este: Cantino (1889); Cantino (1909).

14 Harrise was the first to notice this. See Cantino, A. (1889, pp. 13-15).

15 For an in-depth study of the economic value of the Cantino's Planisphere in relation with other cartographic documents of the time see Moreno Madrid (2019a).

16 See Pade, Petersen and Quarta (1990, pp. 71-90); Tuohy (2002).

17 "The Caverio in its configurations, placenames, and general geographical conceptions is closely related to the Cantino planisphere. The Cantino is a copy of the Portuguese Padrão, made slightly earlier than the Cavverio, by a portuguese cartographer, with inscriptions added by an Italian and Illuminated by Flemish artists and miniaturists", in McIntosh (2015, p. 14).

18 It seems that Domenico Pisani was also a "top level" spy in the Reyes Católicos court. See Cro (2003, p. 54).

19 The arrival of Vasco de Gama in India endangered the Venetian trade in the East. This led to an unstable relationship between Portugal and Venice throughout the sixteenth century. See Marqués de Oliveira (1994).

20 Archivo General de Indias [AGI], Indiferente, 427, 1. 29, f. $109 \mathrm{v}-110 \mathrm{v}$. "Porque se tiene entendido que en las nuevas cartas que se hacen en Portugal con artificio se abrevian y estrechan los viajes y navegación que hacen a las Indias por su demarcación los portugueses por entender mal los límites de ella y alargan la que se hace de España conviene que con la disimulación que el caso pide procure entender todo lo que de este particular hubiere y siempre haber a las manos lo que en esto se hiciere con la industria que se requiere." All transcriptions and translations of original documents are by the author.

21 Studies on this expedition are not particularly abundant. See Oliveira (2011, pp. 4-6); Lima Sobrinho (1946, p. 7).

22 AGI, Indiferente, 1092, n. 153. "[...] Este ha traído cartas y un libro de las cosas de allá de un Fernando de la Torre castellano, que era el capitán de los castellanos que habían allí quedado y estas cartas que este traía de este Hernan[do] para su Majestad; y en Lisboa le tomaron las cartas y el libro un oficial del S[rnmo] rey y no se las han querido dar..."

23 Fernández de Navarrete quotes: "Declaraciones de Andrés de Urdaneta y Macías del Poyo en el interrogatorio que les tomó el Consejo de Indias sobre el viaje de Loaísa" and "Relación presentada al Emperador por Andrés de Urdaneta sobre sucesos de la Armada de Loaísa desde el 24 de julio de 1525 hasta 1535." In: Fernández de Navarrete (1837, pp. 376-396 and 401-440).

24 AGI, Indiferente, 1965, 1. 13, f. 223; AGI, Indiferente, 1965, 1. 13 , f. $220 \mathrm{v}-221$

25 AGI, Indiferente, $1965,1.13$, f. $222 \mathrm{r}-222 \mathrm{v}$.

26 AGI, Indiferente, 1965, 1. 13, f. 286v. "He sido informado que en poder del fiscal Fran[cis]co Mejia está una carta de marear y un astrolabio que se tomó a un portugués, lo cual dice q[ue] es $\mathrm{n}$ [uest]ro y porque es bien que se traiga a $\mathrm{n}$ [uest]ro Consejo de las Indias para que esté en él; os mando que proveáis como se traiga luego."

27 The Ordenanzas of 1552 stipulated that the nautical instruments and charts manufactured in the Casa de la Contratación should be approved and marked by the Piloto Mayor, and only then could the owners trade with them. There is no indication to clarify if the tools of this case were produced in the Casa de la Contratación following this process. In: Sánchez (2010, p. 625.)
28 AGI, Panamá, 233, 1. 1, f. 138r-138v.

29 AGI, Indiferente, $427,1.29$, f. $137 \mathrm{r}$.

30 AGI, Indiferente, $427,1.29$, f. $137 \mathrm{v}$.

31 The original document can be consulted at: AGI, Filipinas, 34, N.4.

32 According to López de Velasco's account, Gesio's booty consisted of "More than a dozen of rutters; two accounts of the journey of Ferdinand Magellan; a treatise on the land of Brazil; the copy of a rutter from the mouth of the Red Sea strait to Suez; no doubt the work of Dom João de Castro, with only a slightly different title, which later became well known in Europe; and even a transcription of Esmeraldo Situ Orbis by Duarte Pacheco Pereira, which Velasco classifies as a very important book and very good for the bookstore." Translated by the author. In: Albuquerque (1974, p. 210)

33 AGI, Indiferente, 418, 1. 2, f. 147v(1).

34 AGI, Indiferente, 418, 1. 2, f. 155v-156v.

35 AGI, Indiferente, $418,1.2$, f. $157 \mathrm{r}$.

36 AGI, Indiferente, $418,1.3$, f. $65 \mathrm{r}(1)$.

37 AGI, Indiferente, 419, 1. 6, f. 542v-543r.

38 Biblioteca Nacional de España [BNE], Mss/9441, f. 19r. The Libro de Longitudes was published by Antonio Blázquez and Delgado Aguilera (1921). More recently, Mariano Cuesta published a compilation of works by Alonso de Santa Cruz that also included the Libro de Longitudes. See Cuesta Domingo (1983).

39 BNE, Mss/9441, f. 20r-21v. "Don Joan de Castro, caballero muy docto y muy curioso que había ido a la India muchas veces y había hecho la descripción de ella de punto muy grande poniendo por escrito y en pintura los puertos, ríos y bajos que a la entrada y dentro de ellos están con las historias de las cosas notables de las tierras y lugares que en ellas están y otro tanto hizo de todo el mar Bermejo porque todo lo anduvo hasta el lugar de Suez que es el más septentrional del dicho mar y puesto en el fin de él donde el gran turco tiene todas sus galeras con que infesta todos aquellos mares, de los cuales libros me dio el traslado con que no los mostrase a ninguna persona de Portugal para que hiciese de manera que la memoria de obras tan insignes y de tanta curiosidad no se perdiese."

40 Albuquerque discusses the veracity of the nautical data and measurements that Dom João de Castro would have given to Alonso de Santa Cruz. He does not doubt, however, that the meeting took place or that Dom João de Castro could have handed over some of his materials to the Castilian cosmographer. In: Albuquerque (1974, p. 204).

41 On the organization of this institution see the recent study: Barreto Xavier (2018).

42 Pedro Nunes was already named "Cosmographer of the Kingdom" on November 16, 1529. In: Leitão (2003, p. 64).

43 Among many others: Acosta Rodríguez, Gonzaléz Rodríguez and Vilar-Vilar (2003); Ladero Quesada (2002); Cervera Pery (1997); León Guerrero (2003).

44 On Juan Díaz de Solís see, among others, Toribio Medina (1897) and Cerezo Martínez (1994, pp. 154-156).

45 On the transfer of nautical knowledge from Spain to England through Cabot see Sandman and Ash (2004). See also, for a more general approach to the Iberian influence on the development of Anglo-Saxon nautical expertise: Waters (1970).

46 The Faleiro brothers (Rui and Francisco) arrived in Seville around 5 December 1517, a month after Magellan did. In Garcia (2019). The transmission of cartographic knowledge on the occasion of the circumnavigation will be dealt with in this same dossier by Antonio Sánchez in the paper entitled Making a Global Image of the World: the First Circumnavigation of the Earth, the Casa de la Contratación of Seville, and the Royal Pattern Chart.

47 For an analysis of Francisco Faleiro's activity in the Casa de la Contratación in Seville, see Collins (2013).

48 AGI, Indiferente, 1961, 1. 3, f. 209

49 AGI, Indiferente, 1961, 1. 3, f. 284

50 AGI, Indiferente, 1961, 1. 3, f. 284.

51 AGI, Indiferente, 1962, 1. 5, f. 190r-190v.

52 On this issue and the confrontation pilots vs. cosmographers see 
Brendecke, (2016, pp. 155-217).

53 AGI, Indiferente, 1962, 1. 6, f. 63v.

54 AGI, Chile, 165, 1. 1, f. 35v. Reproduced in Toribio Medina $(1889$, p. 398).

55 The account of this expedition can be read at: Guillén Tato (1943) and Moreno Madrid and Leitão (2020, pp.133-137).

56 AGI, Chile, $165,1.1$, f. 35v.

57 AGI, Indiferente, 1966, 1. 15, f. 18r.

58 AGI, Indiferente, 1966, 1. 15, f. 30r.

59 AGI, Indiferente, 1966, 1. 15, f. 18r

60 For a study of the duties on board of the captain, master, boatswain and pilot see Pérez-Mallaína (1992).

61 Even if they do not link directly to our time frame, I cannot fail to mention here the work on pilots by Amelia Polonia. See Polónia (1995).

62 On Portuguese pilots in the Rio de la Plata in the sixteenth century see Laguarda Trías (1988)

63 AGI, Indiferente, 1963, 1. 9, f. 282r.

64 AGI, Indiferente, 1963, 1. 9, f. 282r.

65 Collins $(2014$, p. 190) proposes here that their hiring was due to the fact that they "were successful in getting the Council of Indies to intervene in their favour", but the documents and context suggest that they had more to do with the need to get pilots for the Flota de Nueva España. In fact, Nuñez's case reveals a clear urgency to take over his services.

66 AGI, Indiferente, 1968, 1. 19, f. 248-248v.

67 AGI, Indiferente, 1968, 1. 19, f. 266v-267v.

68 AGI, Indiferente, $1968,1.20$, f. 241-241v.

69 AGI, Indiferente, 1963, 1. 7, f. 84r-84v.

70 AGI, Indiferente, 1963, 1. 8, f. 46v-47.

71 AGI, Indiferente, 1962, 1. 6, f. 151r.

72 AGI, Indiferente, 1962, 1. 4, f. 178v.

73 AGI, Indiferente, 1962, 1. 4, f. 178-179r.

74 AGI, Indiferente, 1962, 1. 6, f. 151v. "[...] Piloto examinado y contramaestre y dos marineros que sepan echar el punto en la carta y tomar el sol, a los cuales el dueño del navío haya de ir obligado a dar de ventaja seis ducados a cada uno."

75 AGI, Indiferente, 423, 1. 19, f. 372v-373r. "Ítem. Pues decís que el uno de los q[ue] quiere ir en esa armada que se llama Pedro Alvin es castellano y ha andado siempre en la navegación de $\mathrm{n}$ [uest]ros reinos y territorios y q[ue] tiene experiencia y plática de semejante descubrim[iento]; haberleis vos como de v[uest] ro [...] si fuese posible encaminadle q[ue] viniese acá dándole a entender q[ue] venido vista la habilidad de su forma le mandaremos favorecer y hacer $\mathrm{m}$ [erce]d empleándole en $\mathrm{q}[\mathrm{ue}]$ pueda ser aprovechado y esto sin que parezca q[ue] de acá se ordenó lo dicho."

76 Amélia Polónia and Liliana Oliveira exemplify this search for new job opportunities in the case of the Algarve pilots who were examined in Seville between 1574 and 1650. See Polónia and Oliveira (2020, p. 145).

\section{REFERENCES}

Acosta Rodríguez, A., González Rodríguez, A. and Vilar-Vilar, E., eds. (2003) La Casa de la Contratación y la navegación entre España y las Indias. Sevilla: Universidad de Sevilla/CSIC/Fundación El Monte.

Albuquerque, L. (1974) Estudos de História. Vol. I. Coimbra: Universidade de Coimbra.

Alves, D. V. (2018) "Reconsiderações Historiográficas sobre a Teoria do Sigilo de Jaime Cortesão." Expedições: Teoria da História e da Historiografia, 9 (3), pp. 36-57. Available at: https://www.revista.ueg.br/index.php/revista_geth/article/ view/7713 [Accessed 3 Mar. 2020].

Andrés, G. (1967) Juan Bautista Gesio, cosmógrafo de Felipe II y portador de documentos geográficos desde Lisboa para la biblioteca de El Escorial en 1573. Madrid: Aguirre.

Barreto Xavier, A. (2018) "The Casa da Índia and the Emergence of a Science of Administration in the Portuguese Empire." Journal of Early Modern History, 22 (5), pp. 327-347. doi: https://doi. org/10.1163/15700658-12342599
Bellini, G. (2008) Dal Mediterraneo al mare océano. Alicante: Biblioteca Virtual Miguel de Cervantes. Available at: http://www. cervantesvirtual.com/obra/dal-mediterraneo-al-mare-oceano-saggi-tra-storia-e-letteratura-0/ [Accessed 4 Mar. 2020].

Blair, E. H. and Robertson, J. A. (1906) The Philippine Islands, 1493-1898. Vol. 34. Cleveland: The Arthur H. Clark Company.

Brendecke, A. (2016) Imperio e información. Funciones del saber en el dominio colonial español. Madrid/Frankfurt: Iberoamericana/Vervuert.

Brotton, J. (2014) Historia del mundo en 12 mapas. Barcelona: Debate.

Cantino, A. (1889) Document inédit concernant Vasco da Gama: relation adressée a Hercule d'Este, Duc de Ferrare. H. Harrisse, ed. Paris.

Cantino, A. (1909) Carta d'Alberto Cantino, de 1501 ao Duque de Ferrara. E. do Canto, ed. Lisboa: Imprensa Nacional.

Caracciolo Aricò, A. (1992) "L'immagine del nuovo mondo nella cultura veneziana del cinquecento.' Revue suisse des littératures romanes, 22 , pp. $69-89$.

Caraci, G. (1950) "An unknown nautical chart of grazioso Benincasa, 1468." Imago Mundi, 7, pp. 18-31. doi: https://doi. org/10.1080/03085695008591953

Cattaneo, A. (s.d) "Portugal and the Italian cities (s.XIV-XVI)." Enciclopedia Virtual da Expansão Portuguesa. Available at: http://eve.fcsh.unl.pt/ [Accessed 3 Mar. 2020].

Cerezo Martínez, R. (1994) La cartografía náutica española en los siglos XIV, XV y XVI. Madrid: CSIC.

Cervera Pery, J. (1997) La Casa de la Contratación y el Consejo de Indias (las razones de un superministerio). Madrid: Ministerio de Defensa.

Collins, E. (2013) "Francisco Faleiro and Scientific Methodology at the Casa de la Contratación in the Sixteenth Century." Imago Mundi, 65, pp. 25-36. doi: https://doi.org/10.1080/03085694.2 013.731202

Collins, E. (2014) "Portuguese pilots at the Casa de la Contratación and the exámenes de pilotos." International Journal of Maritime History, 26 (2), pp. 179-192. doi: https://doi.org/10.1177/0843871414527399

Collins, E. (2019) "Interactions of Portuguese artisanal culture in the maritime enterprise of $16^{\text {th }}$ century Seville." Centaurus, 60 (3), pp. 203-215. doi: https://doi.org/10.1111/1600-0498.12188

Cortesão, A. and Mota, A. T. da (1960) Portugaliae Monumenta Cartographica. 6 Vols. Lisboa: Comissão para as Comemorações do V Centenário da Morte do infante D. Henrique.

Cortesão, A. and Mota, A. T. da (1987) Portugaliae Monumenta Cartografica. Vol. I. Lisboa: Imprensa Nacional/Casa da Moeda.

Cortesão, J. (1960) A política do sigilo nos Descobrimentos: nos tempos do Infante D. Henrique e D. João II. Lisboa: Comissão Executiva das Comemorações do Quinto Centenário da Morte do infante D. Henrique.

Cro, S. (2003) "La Princeps y la cuestión del plagio del De Orbe Novo." Cuadernos para investigación de la literatura hispánica, 28, pp. 15-240. Available at: http://www.fuesp.com/ pdfs_revistas/cilh/28/cilh-28-1.pdf

Cuesta Domingo, M., ed. (1983) Alonso de Santa Cruz y su obra cosmográfica. Tomo I. Madrid: CSIC.

Departamento de Difusión del AGS, ed. (2018) Espías: Servicios secretos y escrituras cifradas en la Monarquía Hispánica. Madrid: Ministerio de Cultura y Deporte.

Diffie, Bailey (1969) "Foreigners in Portugal and the 'Policy of Silence'." Terra Incognita, 1, pp. 23-34. doi: https://doi. org/10.1179/tin.1969.1.1.23

Domingues, F. C. (1990) "Colombo e a política de sigilo na historiografia portuguesa." Bolletino della Societá Geografia Italiana, 7(11), pp. 181-198.

Donoso Anes, R. (1996) Una contribución a la Historia de la Contabilidad: Análisis de las prácticas contables desarrolladas por la tesorería de la Casa de la Contratación de las Indias de Sevilla (1503-1717). Sevilla: Universidad de Sevilla.

Esteban Piñeiro, M. (1999) "Los cosmógrafos del rey." In: A. Lafuente and J. Moscoso, eds., Madrid, ciencia y corte. Madrid: CSIC, pp. 121-135. 
Fernandes, F. L. (2003) O Planisferio de Cantino e o Brasil. Lisboa: Academia de Marina, 2003.

Fernández de Navarrete, M. (1837) Colección de los viajes y descubrimientos que hicieron por mar los españoles desde fines del siglo $X V$ : con varios documentos inéditos concernientes a la historia de la marina castellana y de los establecimientos españoles en Indias. Vol. 5. Madrid: Imprenta Nacional.

Fernández Vial, I. (2011) "Juan Rodríguez Mafra y los marinos onubenses en la primera vuelta al mundo." In: Actas de las Jornadas de Historia sobre el Descubrimiento de América. Tomo II. Sevilla: Universidad Internacional de Andalucía, pp. 75-101.

Fernández-López, F. (2018) "El proceso de admisión de maestres de navíos en la Casa de la Contratación: expedientes y procedimiento." Anuario de Estudios Americanos, 75 (1), pp. 43-66. doi: https://doi.org/10.3989/aeamer.2018.1.02

García, J. M. (2015) O início dos Descobrimentos com o Infante D. Henrique. Vila do Conde: Verso da História.

García, J. M. (2019) Fernão de Magalhães. Herói, traidor ou mito: a história do primeiro homem a abraçar o mundo. Lisboa: Manuscrito.

García Barreno, P. (2020) "Sobre la institución de la Academia Real Matemática en tiempos de Felipe II." Boletín de Información Lingüística de la Real Academia Española. pp. 3-131. Available at: http://revistas.rae.es/bilrae/article/view/408/889 [Accessed: 11 Apr. 2020].

García Redondo, J. M. (2018) Cartografía e Imperio. El Padrón Real y la representación del Nuevo Mundo. Aranjuez: Ediciones Doce Calles.

García Redondo, J. M. and Varela, C. (2013) "Ecos literarios y memoria cartográfica del Famous Voyage de Francis Drake." Anuario de Estudios Americanos, 70 (2), pp. 441-478. DOI: https://doi.org/10.3989/aeamer.2013.2.03

Gaspar, J. A. (2012) "Blunders, Errors and Entanglements: Scrutinizing the Cantino Planisphere with a Cartometric Eye." Imago Mundi, 64 (2), pp. 181-220. doi: https://doi.org/10.1080/ 03085694.2012 .673762

Gaspar, J. A. (2015) "Da Carta-Portulano Do Mediterrâneo à Carta de Latitudes Do Atlântico." In: Memórias da Academia de Marinha, 41, Lisboa: Academia de Marinha, pp. 237-257.

Gaspar, J. A. and Leitão, H. (2018a) "Luís Teixeira, c. 1585: The Earliest Known Chart with Isogonic Lines." Imago Mundi, 70, pp. 221-228. doi: https://doi.org/10.1080/03085694.2018.14505 54.

Gaspar, J. A. and Leitão, H. (2018b) "What is a nautical chart, really? Uncovering the geometry of early modern nautical charts." Journal of Cultural Heritage, 29, pp. 130-136. doi: https://doi.org/10.1016/j.culher.2017.09.008.

Gaspar, J. A. and Leitão, H. (2019) "Early Modern Nautical Charts and Maps: Working Through Different Cartographic Paradigms." Journal of Early Modern History, 23, pp. 1-28. doi: https://doi.org/10.1163/15700658-12342627.

Goodman, D. C. (1992) Power and Penury: Government, Technology and Science in Philip II's Spain. Cambridge: Cambridge University Press.

Guillén Tato, J., ed. (1943) Colección de diarios y relaciones para la historia de los viajes y descubrimientos. Vol. I. Madrid: CSIC/ Instituto Histórico de la Marina.

Harley, J.B. (1988) "Silences and Secrecy: The Hidden Agenda of Cartography in Early Modern Europe." Imago Mundi, 40, pp. 57-76. doi: https://doi.org/10.1080/03085698808592639

Jons, H. (2011) "Centre of calculation." In: J. Agnew and D. N. Livingstone, eds., The SAGE Handbook of Geographical Knowledge. London: Sage Publications, pp. 158-170. Available at: https://www.researchgate.net/publication/267035207_ Centre_of_calculation [accessed Mar 12 2020].

Ladero Quesada, M.A (2002) El primer oro de América: los comienzos de la Casa de la Contratación de las Yndias (15031511). Madrid: Real Academia de la Historia.

Laguarda Trías, R. A. (1988) "Pilotos portugueses en el Río de la Plata durante el siglo XVI." Revista da Universidade de Coimbra, 34, pp. 57-84.
Leitão, H. (2003) "Para uma biografia de Pedro Nunes: O surgimento de um matemático, 1502-1542." Cadernos de Estudos Sefarditas, 3, pp. 45-82.

Leitão, H. and Gaspar, J. A. (2014) "Squaring the Circle: How Mercator Constructed his Projection in 1569." Imago Mundi, 66, pp. 1-24. doi: https://doi.org/10.1080/03085694.2014.845940

Leitão, H. and Sánchez, A. (2017) "Zilsel's Thesis, Maritime Culture, and Iberian Science in Early Modern Europe." Journal of the History of Ideas, 78 (2), pp. 191-210. doi: https://doi. org/10.1353/jhi.2017.0010

León Guerrero, M. M. (2003) "La Casa de la Contratación: precedentes inmediatos.” Revista de Humanidades: Tecnológico de Monterrey, 15, pp. 163-186.

Lima Sobrinho, B. (1946) O devassamento do Piauí. Brasil: Companhia Editora Nacional. Available at: https://bdor.sibi. ufrj.br/bitstream/doc/341/1/255\%20PDF\%20-\%20OCR\%20 -\%20RED.pdf [Accessed 3 Mar. 2020].

Livingstone, D. N. (2003), Putting science in its place: geographies of scientific knowledge. Chicago/London: The University of Chicago Press.

Marcondes de Souza, T. O. (1958) "A política do sigilo dos monarcas portugueses da época dos descobrimentos marítimos." Revista de História, 34 (16), pp. 257-273.

McIntosh, G. (2015) The Vesconte Maggiolo World Map of 1504 in Fano, Italy - 2nd Edition. Cerritos: Plus Ultra Publishing Company.

Medina, J. T. (1889) Colección de documentos inéditos para la historia de Chile, desde el viaje de Magallanes hasta la batalla de Maipo, 1518-1818. Expediciones de Jofré de Loaísa, Alcazaba, Mendoza, Camargo, etc. Santiago de Chile: Imprenta Ercilla.

Medina, J. T. (1897) Juan Díaz de Solís: Estudio Histórico. Santiago de Chile: Impreso en casa del autor.

Milano, E. (2004) Carta del Cantino: All' Edizione in Facsímile. Módena: Il Bulino.

Moreno Madrid, J. M. (2019a) "El valor económico de la cartografía en la Época de los Descubrimientos: un estudio comparativo a partir del Planisferio de Cantino (1502)." Tiempos Modernos, 9 (39), pp. 96-114. http://www.tiemposmodernos.org/tm3/index. $\mathrm{php} / \mathrm{tm} /$ article/view/5206/869.

Moreno Madrid, J. M. (2019b) "De espionaje y cartas náuticas: el impacto de América en la Europa de principios del siglo XVI." Naveg@merica. Revista electrónica editada por la Asociación Española de Americanistas, 23. doi: https://doi.org/10.6018/ nav.397331

Moreno Madrid, J. M. and Leitão, H. (2020) Atravessando a Porta do Pacífico. Roteiros e Relatos da Travessia do Estreito de Magalhães, 1520-1620. Lisboa: ByTheBook.

Mota, A. T. da (1969) Os regimentos do cosmógrafo-mor de 1559 e 1592 e as origens do ensino náutico em Portugal. Lisboa: Junta de Investigações do Ultramar.

Nuttall, Z., ed. (1914) New light on Drake. A collection of documents relating to his voyage of circumnavigation, 1577-1580. London: Hakluyt Society.

Oliveira, J. M. de (1994) Veneza e Portugal no século XVI. Vol. I. Lisboa: Biblioteca Nacional de Portugal.

Oliveira, L. F. (2011) "Estado do Maranhão e Grão-Pará: primeiros anos de ocupação, expansão e consolidação do territorio." Anais do XXVI Simpósio Nacional de História. São Paulo: ANPUH. Available at: http://www.snh2011.anpuh.org/resources/ anais/14/1300473062_ARQUIVO_ArtigoAnpuhUSP2011[1]. pdf [Accessed 3 Mar. 2020].

Pade, M., Petersen, L. and Quarta, D. (1990) Court of Ferrara and its patronage. Copenhagen: Museum Tusculanum Press.

Padrón, R. (2004) The spacious Word: Cartography, Literature, and Empire in Early Modern Spain. Chicago: The University of Chicago Press.

Paladini Cuadrado, A. (2000) "La formación de la carta moderna del mundo en el siglo XVI." Monte Buciero, 4, pp. 61-70.

Pérez Mallaína, P. E. (1992) Spain's Men of the Sea. Daily life on the Indies Fleets in the Sixteenth Century. Baltimore/London: John Hopkins University Press. 
Pérez-Mallaína, P. E. (2002) "Educación y transmisión de conocimientos en la Carrera de Indias en el siglo XVI.” In: A. Vala Lorenzo, ed., Educación y transmisión de conocimientos en la historia. Salamanca: Ediciones Universidad de Salamanca, pp. 211-231.

Polónia, A. (1995) "Mestres e pilotos das carreiras ultramarinas (1596-1648)." Revista da Faculdade de Letras da Universidade do Porto, 12, pp. 271-354. Available at: https://repositorioaberto.up.pt/handle/10216/8785 [Accessed Mar. 18 2020].

Polónia, A. and Oliveira, L. (2020) "Shipping and empire building: crown versus individuals in Portuguese overseas expansion, c.1500-1700. A mixed model of development." The International Journal of Maritime History, 32 (1), pp. 134-148. doi: https://doi.org/10.1177/0843871419886801

Portuondo, M. M. (2009) Secret Science: Spanish Cosmography and the New World. Chicago: The University of Chicago Press.

Pulido Rubio, J. (1950) El Piloto Mayor. Pilotos Mayores, Catedráticos de Cosmografía y Cosmográfos de la Casa de la Contratación de Sevilla. Sevilla: Escuela de Estudios HispanoAmericanos, CSIC.

Radulet, C. M. (1991) Os descobrimentos portugueses e a Itália. Lisboa: Vega.

Recopilación de Leyes de los Reinos de las Indias, mandadas imprimir y publicar por la Magestad Católica del rey Don Carlos II, Nuestro Señor, vol. 3 (1841). Madrid: Boix

Relaño, F. (2002) The Shaping of Africa: Cosmographic Discourse and Cartographic Science in Late Medieval and Early Modern Europe. Farnham: Ashgate Publishing.

Rueda Ramírez, P. J. (2002) "El comercio de libros en la Carrera de Indias.” In: C. Castañeda and M. Cortés, coords., Del autor al lector. México D. F.: CIESAS, pp. 45-71.

Sánchez, A. (2010) "Los artífices del Plus Ultra: Pilotos, cartógrafos y cosmógrafos en la Casa de la Contratación de Sevilla durante el siglo XVI.” Hispania, 70 (236), pp. 607-632. doi: https://doi. org/10.3989/hispania.2010.v70.i236.326
Sánchez, A. (2013) La espada, la cruz y el Padrón: Soberanía, fe y representación cartográfica en el mundo ibérico bajo la Monarquía Hispánica, 1503-1598. Madrid: CSIC.

Sánchez, A. (2019) "Artesanos, cartografía e imperio. La producción social de un instrumento náutico en el mundo ibérico, 1500-1650." Historia Crítica, 73, pp. 21-41. doi: https://doi.org/10.7440/histcrit73.2019.02

Sandman, A. (2008) "Controlling Knowledge: Navigation, Cartography, and Secrecy in the Early Modern Spanish Atlantic." In: J. Delbourgo and N. Dew, eds., Science and Empire in the Atlantic World. New York: Routledge, pp. 31-51.

Sandman, A. and Ash, E. H. (2004) "Trading expertise: Sebastian Cabot between Spain and England." Renaissance Quarterly, 57 (3), pp. 813-843. https://www.jstor.org/stable/4143567.

Santa Cruz, A. y Blázquez y Delgado-Aguilera, A., eds. (1921) Libro de las Longitudes y manera que hasta agora se ha tenido en el arte de navegar, con sus demostraciones y ejemplos. Sevilla: Tip. Zarzuela. Available at: http://www.bibliotecavirtualdeandalucia.es/catalogo/ es/consulta/registro.cmd?id=3823 [Accessed Mar 18 2020].

Tuohy, T. (2002) Herculean Ferrara: Ercole D'Este (1471-1505) and the invention of a Ducal Capital. Cambridge: Cambridge University Press.

Varela, C. (1998) “Política y propaganda en el mapa de Cantino.” In: Limites do Mar e da Terra: Actas VIII Reunião Internacional de História da Náutica e Hidrografia. Cascais: Patrimonia.

Wagner, K. (1994) "Guido de Lavezaris, genovés (1512-1583): De librero a gobernador de Filipinas." In: V. Piergiovanni, ed., Tra Siviglia e Genova: notaio, documento e commercio nell'età colombiana: tai del convengo internazionale di studi storici per le celebración colombiane organizzato dal consiglio notarile dei distretti riuniti di Genova e Chiavari sotto l'egida del consiglio nazionale del notariato (Genova, $12-14$ marzo 1992). Milano: Dott. A. Giuffrè Editore, pp. 378-391.

Waters, David (1970) "The Iberian Bases of the English Art of Navigation in XVICentury." In: Agrupamento de Estudos de Cartografia Antiga, Separata XXXVII. Lisboa: Junta de Investigações do Ultramar 